\author{
Anna MEYŃSKA ${ }^{1}$ \\ Krzysztof CHMIELOWSKI ${ }^{2}$ \\ Dariusz MŁYŃSKI ${ }^{3}$
}

\title{
REDUKCJA ZWIĄZKÓW BIOGENNYCH NA WYBRANYCH OCZYSZCZALNIACH ŚCIEKÓW WOJEWÓDZTWA PODKARPACKIEGO Z UWZGLECDNIENIEM WARUNKÓW POGODY SUCHEJ I MOKREJ
}

\begin{abstract}
W artykule dokonano analizy stopnia redukcji azotu ogólnego i fosforu ogólnego osiągniętego w 2015 roku na dwóch wybranych oczyszczalniach województwa podkarpackiego. Jak się okazuje, zachodzące w nich procesy biologicznego oczyszczania ścieków zapewniły wysoki poziom redukcji związków biogennych. Zauważono, że na skuteczność zmniejszania koncentracji związków azotu i fosforu nie wpłynęły warunki pogodowe związane $\mathrm{z}$ występowaniem bądź niewystępowaniem opadów atmosferycznych. Istnieje bowiem zagrożenie, że nadmierne ilości wód opadowych w systemach kanalizacyjnych powodują zmniejszanie ilości materii organicznej podatnej na biodegradację na skutek rozcieńczania ścieków i w konsekwencji obniżenie skuteczności usuwania zanieczyszczeń.
\end{abstract}

Słowa kluczowe: ścieki, oczyszczalnia, redukcja, azot ogólny, fosfor ogólny, pogoda bezdeszczowa, pogoda deszczowa

\section{Wprowadzenie}

Zaostrzenie prawnych regulacji dotyczących maksymalnych ilości związków azotu i fosforu, które mogą zostać odprowadzone do środowiska naturalnego wraz ze ściekami oczyszczonymi wymusiło na wielu eksploatatorach oczyszczalni przeprowadzenie prac modernizacyjnych, głównie pod kątem osiągnięcia jak największej skuteczności eliminacji związków biogennych. Przed laty, część

\footnotetext{
${ }^{1}$ Autor do korespondencji / corresponding author: Anna Młyńska, Politechnika Krakowska, Instytut Zaopatrzenia w Wodę i Ochrony Środowiska, ul. Warszawska 24, 31-155 Kraków; a.mlynska13@gmail.com

2 Krzysztof Chmielowski, Uniwersytet Rolniczy, Katedra Inżynierii Sanitarnej i Gospodarki Wodnej, al. Mickiewicza 24/28, 30-059 Kraków; k.chmielowski@ur.krakow.pl

3 Dariusz Młyński, Uniwersytet Rolniczy, Katedra Inżynierii Sanitarnej i Gospodarki Wodnej, al. Mickiewicza 24/28, 30-059 Kraków; dariusz.mlynski@gmail.com
} 
funkcjonujących obiektów w ogóle nie była przystosowana do usuwania biogenów bądź była przystosowana lecz w niewystarczającym stopniu, o czym świadczyły wciąż wysokie ich stężenia w ściekach odpływających z oczyszczalni, co z kolei skutkowało intensyfikacją procesów eutrofizacji w naturalnych zbiornikach wodnych.

Właściwa skuteczność procesów usuwania związków azotu na drodze nitryfikacji i denitryfikacji oraz usuwania związków fosforu osiągnięta zostanie, jeśli w poszczególnych obiektach technologicznych oczyszczalni stworzone zostaną właściwe warunki, związane głównie z zapewnieniem dostatecznej zawartości materii organicznej podatnej na biodegradację oraz odpowiedniej ilości tlenu, wartości temperatury czy zakresu pH ścieków [1]. Jedynie w sytuacji, gdy biologiczna defosfatacja ścieków nie przynosi zadowalających efektów, procesy biologiczne zastępuje się bądź wspomaga się głównie procesami strącania chemicznego i koagulacji [2].

Oddziałujące w nadmiarze na systemy kanalizacji ogólnospławnej wody opadowe wpływają negatywnie nie tylko na kanały ściekowe i obiekty sieciowe, ale także na pracę oczyszczalni [3]. Kanalizowanie obszarów systemem kanalizacji rozdzielczej pomaga uniknąć tego typu sytuacji, jednak problem pojawia się wówczas, gdy na kanały sanitarne systemu rozdzielczego oddziałują wody przypadkowe. Źródeł dopływających wód przypadkowych jest wiele, aczkolwiek najczęściej upatruje się ich w postaci wód opadowych lub roztopowych przedostających się do kanalizacji przez otwory i szczeliny we włazach studzienek bądź przez nielegalne podłączanie rynien dachowych i wpustów podwórzowych do kanałów ściekowych $[4,5,6,7,8]$.

Nadmierne oddziaływane wód opadowych, czy to na systemy kanalizacji ogólnospławnej, czy na systemy kanalizacji rozdzielczej prowadzi często do zakłóceń pracy oczyszczalni. Ścieki sanitarne, które pozostają pod znacznym wpływem ścieków opadowych, charakteryzują się zmienionym składem, zwiększonym natlenieniem i rozcieńczeniem, a zbyt duża ilość dopływających ścieków powoduje przeciążenie hydrauliczne poszczególnych urządzeń ciągu technologicznego oczyszczalni, co zakłóca właściwy proces przebiegu usuwania związków biogennych $[9,10]$. Wody przypadkowe pochodzące z topniejącego śniegu lub opadów deszczu powodują wychładzanie się ścieków, co wpływa negatywnie na skuteczność procesów biologicznego oczyszczania, które najefektywniej zachodzą $\mathrm{w}$ warunkach temperatury na poziomie około $20^{\circ} \mathrm{C}[11$, 12]. Co więcej, rozcieńczone wodami opadowymi ścieki charakteryzują się zmniejszonymi wartościami $\mathrm{BZT}_{5}$, hamując procesy denitryfikacji, a także obniżonymi wartościami ChZT i zawiesiny ogólnej [13]. Z badań przeprowadzonych przez Kaczora [14] wynika natomiast, że im większy udział wód przypadkowych w trakcie pogody mokrej, tym także mniejsze jest stężenie azotu ogólnego i fosforu ogólnego w ściekach surowych, jako skutek ich rozcieńczenia.

W artykule przeanalizowano w jakim stopniu obecny w ściekach azot ogólny i fosfor ogólny redukowany był w 2015 roku na dwóch wybranych oczysz- 
czalniach zlokalizowanych na terenie województwa podkarpackiego. Dodatkowo uwzględniono warunki pogody bezdeszczowej i deszczowej celem weryfikacji, czy w okresach trwania pogody mokrej wody opadowe oddziałujące na systemy sanockiej i przemyskiej kanalizacji wpłynęły na poziom redukcji związków azotu i fosforu.

\section{Opis obiektów badań}

\subsection{Oczyszczalnia ścieków w Trepczy}

Oczyszczalnia w Trepczy (RLM 75 920) unieszkodliwia ścieki komunalne i przemysłowe dopływające częściowo ogólnospławnym systemem kanalizacji z obszaru sanockiej aglomeracji, obejmującej gminę wiejską oraz miasto Sanok. Jest to oczyszczalnia mechaniczno-biologiczna, w której procesy mechanicznego oddzielenia części stałych zanieczyszczeń zachodzą kolejno na trzech kratach gęstych, następnie w dwóch piaskownikach oraz w dwóch osadnikach wstępnych poziomych podłużnych. Częśśc biologiczną obiektu stanowią dwa niezależnie funkcjonujące reaktory przepływowe $\mathrm{z}$ wydzielonymi komorami predenitryfikacji, defosfatacji, denitryfikacji i nitryfikacji oraz trzy osadniki wtórne radialne, z których oczyszczone ścieki kierowane są do rzeki San. Przepustowość hydrauliczna obiektu określona została na poziomie $15000 \mathrm{~m}^{3} / \mathrm{d}$, natomiast maksymalna ilość ścieków, którą jest w stanie przyjąć oczyszczalnia w trakcie trwania opadów wynosi $28000 \mathrm{~m}^{3} / \mathrm{d}[15,16,17]$.

\subsection{Oczyszczalnia ścieków w Przemyślu}

Drugi obiekt badań znajdujący się na terenie miasta Przemyśl, charakteryzuje się RLM na poziomie 101833 i ma za zadanie oczyszczanie ścieków komunalnych i przemysłowych doprowadzanych głównie kolektorami kanalizacji ogólnospławnej z obszaru miasta i gminy wiejskiej Przemyśl oraz z gminy Krasiczyn. Oczyszczalnię w Przemyślu zwymiarowano na przepływ średni dobowy równy $28200 \mathrm{~m}^{3} / \mathrm{d}$ oraz przepływ maksymalny dobowy na poziomie $45200 \mathrm{~m}^{3} /$ d. Na przemyskiej oczyszczalni realizowane są procesy mechanicznobiologicznego unieszkodliwiania ścieków, po których to oczyszczone ścieki odprowadzane są bezpośrednio do rzeki San [17]. W skład ciągu technologicznego obiektu wchodzą następujące elementy [18]:

- w części mechanicznej: trzy kraty gęste, dwa piaskowniki poziome oraz dziesięć osadników wstępnych poziomych podłużnych,

- w części biologicznej: cztery komory osadu czynnego z wydzielonymi strefami defosfatacji, denitryfikacji, nitryfikacji i dwiema strefami buforowymi oraz sześć osadników wtórnych radialnych. 


\section{Materialy i metody badawcze}

Dane wyjściowe i materiały, którymi posłużono się w niniejszym opracowaniu obejmują następujące elementy:

1) Odnotowane w 2015 roku wyniki pomiarów parametrów fizykochemicznych 24 próbek ścieków surowych i oczyszczonych, obejmujące swym zakresem stężenia azotu ogólnego $\left(\mathrm{N}_{\text {og. }}\right)$ i fosforu ogólnego $\left(\mathrm{P}_{\text {og. }}\right)$.

2) Dobowe wielkości ilości ścieków dopływających do oczyszczalni w Trepczy i do oczyszczalni w Przemyślu zarejestrowane w 2015 roku.

3) Dane dotyczące wysokości opadów atmosferycznych odnotowanych na terenie zlewni danej oczyszczalni w poszczególnych dniach 2015 roku;

- oczyszczalnia ścieków w Trepczy: dane opadowe zarejestrowane na stacji hydrologiczno-meteorologicznej w Lesku;

- oczyszczalnia ścieków w Przemyślu: dane opadowe zarejestrowane na automatycznej stacji synoptycznej w Przemyślu.

4) Rozporządzenie Ministra Środowiska (Dz.U. 2014 poz. 1800) [19].

Na podstawie odnotowanych wielkości stężeń azotu ogólnego $\left(\mathrm{N}_{\mathrm{og}}\right)$ i fosforu ogólnego $\left(\mathrm{P}_{\mathrm{og}}\right)$ w ściekach surowych i oczyszczonych wyznaczono podstawowe statystyki opisowe, obejmujące wartości minimalne, maksymalne oraz średnie, które porównano z ich wymaganymi wartościami regulowanymi przez obowiązujące Rozporządzenie [19] (tabela 1).

Tabela 1. Dopuszczalne wartości stężenia azotu ogólnego $\left(\mathrm{N}_{\mathrm{og}}\right)$ i fosforu ogólnego $\left(\mathrm{P}_{\mathrm{og}}\right)$ lub ich minimalny procent redukcji w ściekach odprowadzanych do środowiska naturalnego [19]

Table 1. Allowable total nitrogen $\left(\mathrm{N}_{\text {tot. }}\right)$ and total phosphorus $\left(\mathrm{P}_{\text {tot }}\right.$. $)$ concentration values or its minimum percentage reduction in sewage discharged to the environment [19]

\begin{tabular}{|c|c|c|c|c|}
\hline $\begin{array}{c}\text { Nazwa } \\
\text { wskaźnika }\end{array}$ & Parametr & Jednostka & $\begin{array}{c}\text { Oczyszczalnia ścieków } \\
\text { w Trepczy } \\
\text { (RLM 75 920) }\end{array}$ & $\begin{array}{c}\text { Oczyszczalnia ścieków } \\
\text { w Przemyślu } \\
\text { (RLM 101 833) }\end{array}$ \\
\hline $\begin{array}{c}\text { azot ogólny } \\
\left(\mathrm{N}_{\text {og. }}\right)\end{array}$ & stężenie & $\mathrm{mg} / \mathrm{dm}^{3}$ & 15 & 10 \\
\cline { 2 - 6 } & redukcja & $\%$ & \multicolumn{2}{|c|}{$70-80$} \\
\hline $\begin{array}{c}\text { fosfor ogólny } \\
\left(\mathrm{P}_{\text {og. }}\right)\end{array}$ & stężzenie & $\mathrm{mg} / \mathrm{dm}^{3}$ & \multicolumn{2}{|c|}{80} \\
\cline { 2 - 6 } & redukcja & $\%$ & \multicolumn{3}{|c|}{1} \\
\hline
\end{tabular}

Dodatkowo, na podstawie zależności wykorzystanej m.in. przez Chmielowskiego i in. [20], obliczono procentową redukcję $(\eta)$ analizowanych wskaźników zanieczyszczeń w okresach trwania pogody deszczowej (mokrej) oraz w okresach trwania pogody bezdeszczowej (suchej), aby zweryfikować czy na redukcję związków biogennych wpłynęły warunki pogodowe związane z występowaniem bądź niewystępowaniem opadów atmosferycznych. W tym celu, w oparciu o dane opadowe dokonano selekcji, które analizowane dni roku 2015 zaliczane były do okresów pogody suchej, a które do okresów pogody mokrej. Założono, że ścieki poddane procesom oczyszczania pozostawały pod wpływem wód opa- 
dowych, jeśli w danym dniu bądź w dniu, który go poprzedzał odnotowany został opad, i którego wysokość wyniosła co najmniej $1 \mathrm{~mm}$ (pogoda deszczowa). Jako dni z pogodą bezdeszczową potraktowano te, w których opad nie wystąpił bądź nie przekroczył $1 \mathrm{~mm}$.

Mając na uwadze fakt, że w trakcie pogody mokrej oddziałujące na system kanalizacyjny wody przypadkowe mogą powodować nadmierne rozcieńczanie ścieków surowych, co w sposób negatywny przekłada się na efekty usuwania związków biogennych, w oparciu o zarejestrowane ilości ścieków dopływających do analizowanych oczyszczalni, z uwzględnieniem podziału dni na deszczowe i bezdeszczowe oraz w oparciu o zależność (1), którymi posługiwali się także autorzy innych opracowań $[8,12]$, określono średni udział wód przypadkowych oddziałujących w analizowanym okresie na systemy kanalizacyjne sanockiej i przemyskiej aglomeracji.

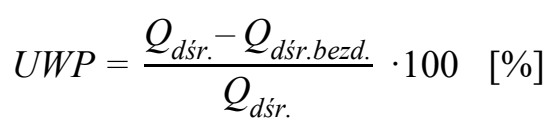

gdzie: $U W P$ - udział wód przypadkowych [\%];

$Q_{d s r}-$ średni dobowy dopływ ścieków do oczyszczalni $\left[\mathrm{m}^{3} / \mathrm{d}\right]$;

$Q_{d s r . b e z d .}$ - średni dobowy dopływ ścieków do oczyszczalni w okresach pogody bezdeszczowej $\left[\mathrm{m}^{3} / \mathrm{d}\right]$.

\section{Opracowanie i analiza wyników badań}

\subsection{Redukcja związków biogennych na oczyszczalni ścieków w Trepczy}

Procesy biologicznego oczyszczania zachodzące w 2015 roku na obiekcie w Trepczy zapewniały wysoki stopień redukcji azotu ogólnego $\left(\mathrm{N}_{\mathrm{og}}\right)$ do stężeń wymaganych przez obowiązujące prawo. Stężenie tego wskaźnika w ściekach oczyszczonych zmieniało się od $7,0 \mathrm{mg} / \mathrm{dm}^{3}$ do $14,6 \mathrm{mg} / \mathrm{dm}^{3}$, osiągając wartość średnio-roczną równą $10,1 \mathrm{mg} / \mathrm{dm}^{3}$, która była o ponad $30 \%$ mniejsza od stężenia dopuszczalnego, wynoszącego $15,0 \mathrm{mg} / \mathrm{dm}^{3}$ (tabela 1 , tabela 2).

Tabela 2. Wartości podstawowych statystyk opisowych dla stężeń azotu ogólnego $\left(\mathrm{N}_{\mathrm{og}}\right)$ i fosforu ogólnego $\left(\mathrm{P}_{\mathrm{og}}\right.$. $)$ w ściekach unieszkodliwianych na oczyszczalni w Trepczy w 2015 roku

Table 2. The values of the basic descriptive statistics for total nitrogen $\left(\mathrm{N}_{\text {tot. }}\right)$ and total phosphorus $\left(\mathrm{P}_{\text {tot. }}\right)$ concentrations in sewage treated on the Wastewater Treatment Plant in Trepcza in 2015

\begin{tabular}{|c|c|c|c|c|c|}
\hline \multirow{2}{*}{$\begin{array}{c}\text { Nazwa } \\
\text { wskaźnika }\end{array}$} & \multirow{2}{*}{ Jednostka } & \multirow{2}{*}{$\begin{array}{c}\text { Rodzaj } \\
\text { ścieków }\end{array}$} & \multicolumn{3}{|c|}{ Statystyka opisowa } \\
\cline { 3 - 6 } & & Min. & Max. & Średnia \\
\hline \multirow{2}{*}{ azot ogólny $\left(\mathrm{N}_{\mathrm{og}}\right)$} & \multirow{2}{*}{$\mathrm{mg} / \mathrm{dm}^{3}$} & surowe & 38,7 & 131,5 & 72,9 \\
\cline { 3 - 6 } & & oczyszczone & 7,0 & 14,6 & 10,1 \\
\hline \multirow{2}{*}{ fosfor ogólny $\left(\mathrm{P}_{\mathrm{og}}\right.$.) } & \multirow{2}{*}{$\mathrm{mg} / \mathrm{dm}^{3}$} & surowe & 7,8 & 61,3 & 22,6 \\
\cline { 3 - 6 } & & oczyszczone & 0,23 & 0,97 & 0,50 \\
\hline
\end{tabular}


Najniższą, niespełna 72\%-ową wartość redukcji azotu ogólnego odnotowano w dniu 8.12., który stanowił dzień bezdeszczowy. $\mathrm{Z}$ kolei największy stopień redukcji $\left(\eta_{\text {max.Nog. }}=91,7 \%\right)$ odnotowano dnia 24.06., należącym do okresu pogody deszczowej. Dodatkowo, pomimo tego iż w 2015 roku średnia redukcja azotu ogólnego $\mathrm{w}$ okresach trwania pogody suchej $\left(\eta_{\text {śr.Nog.bezd. }}=84,4 \%\right)$ była większa od średniej redukcji azotu ogólnego $\mathrm{w}$ okresach trwania pogody deszczowej $\left(\eta_{\text {sr.Nog.deszcz. }}=79,5 \%\right)$, to jednak generalnie nie zauważa się, aby na kształtowanie się tego parametru wpływały warunki pogodowe związane $\mathrm{z}$ występowaniem bądź niewystępowaniem opadów atmosferycznych (rys. 1).

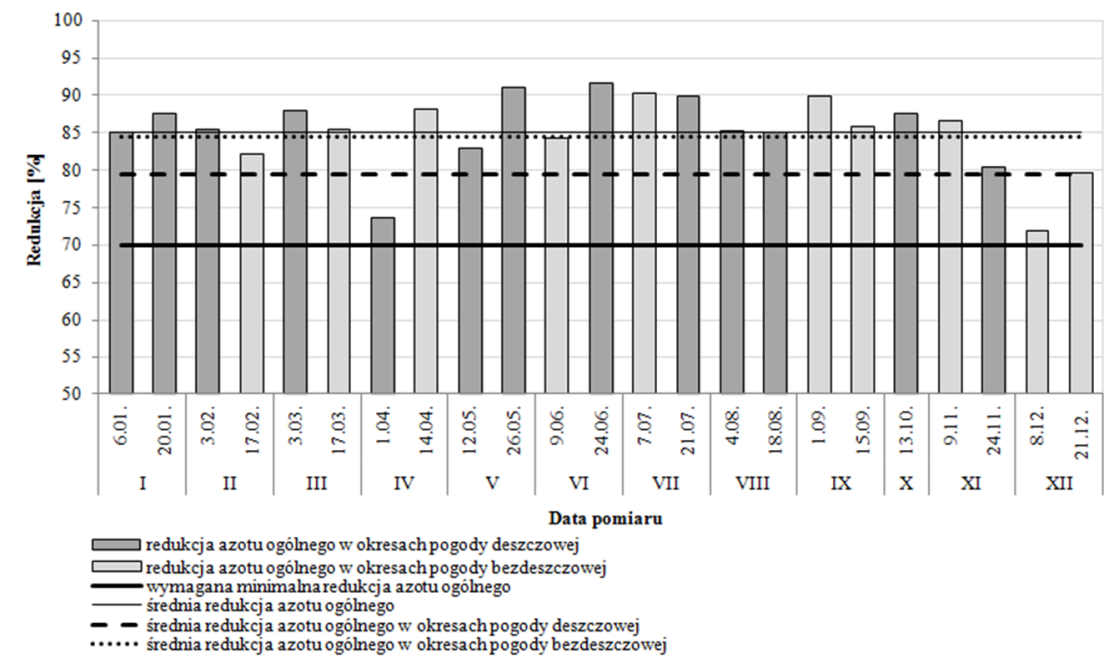

Rys. 1. Redukcja azotu ogólnego na oczyszczalni ścieków w Trepczy w 2015 roku z uwzględnieniem okresów z pogodą deszczową i bezdeszczową

Fig. 1. Total nitrogen reduction on the Wastewater Treatment Plant in Trepcza in 2015 including rainy and rainless weather periods

Średnia wielkość redukcji fosforu ogólnego $\left(\mathrm{P}_{\text {og. }}\right)$ osiągnięta na oczyszczalni w Trepczy ukształtowała się na bardzo wysokim poziomie, bo równym aż 97,6\%. Co więcej, w poszczególnych dniach utrzymywała się na stosunkowo wyrównanych poziomach, o czym świadczą wyznaczone wartości: minimalna $\left(\eta_{\text {min.Pog. }}=94,9 \%\right)$ oraz maksymalna $\left(\eta_{\text {max.Pog. }}=99,1 \%\right)$ (rys. 2). Najmniejsze stężenie fosforu ogólnego, jakie odnotowano w ściekach odprowadzanych do rzeki San wyniosło $0,23 \mathrm{mg} / \mathrm{dm}^{3}$, natomiast maksymalne $-0,97 \mathrm{mg} / \mathrm{dm}^{3}$, co oznacza, że każdorazowo wielkość tego parametru mieściła się w granicach określonych w Rozporządzeniu Ministra Środowiska [19] (tabela 1, tabela 2). Uwzględniając natomiast podział analizowanych dni na okresy deszczowe i bezdeszczowe wykazano, że pojawienie się opadów w żaden sposób nie wpłynęło na redukcję fosforu ogólnego. Świadczy o tym chociażby to, że najmniejszy osiągnięty stopień redukcji związków fosforu odnotowany został w dniach 9.06. i 21.12., które nie 
pozostawały pod wpływem opadów, a średnia redukcja tego wskaźnika w czasie pogody mokrej $\left(\eta_{\text {sr.Pog.deszcz. }}=97,8 \%\right)$ była zbliżona do tej przypisywanej pogodzie suchej $\left(\eta_{\text {śr.Pog.bezd. }}=97,3 \%\right)$ (rys. 2).

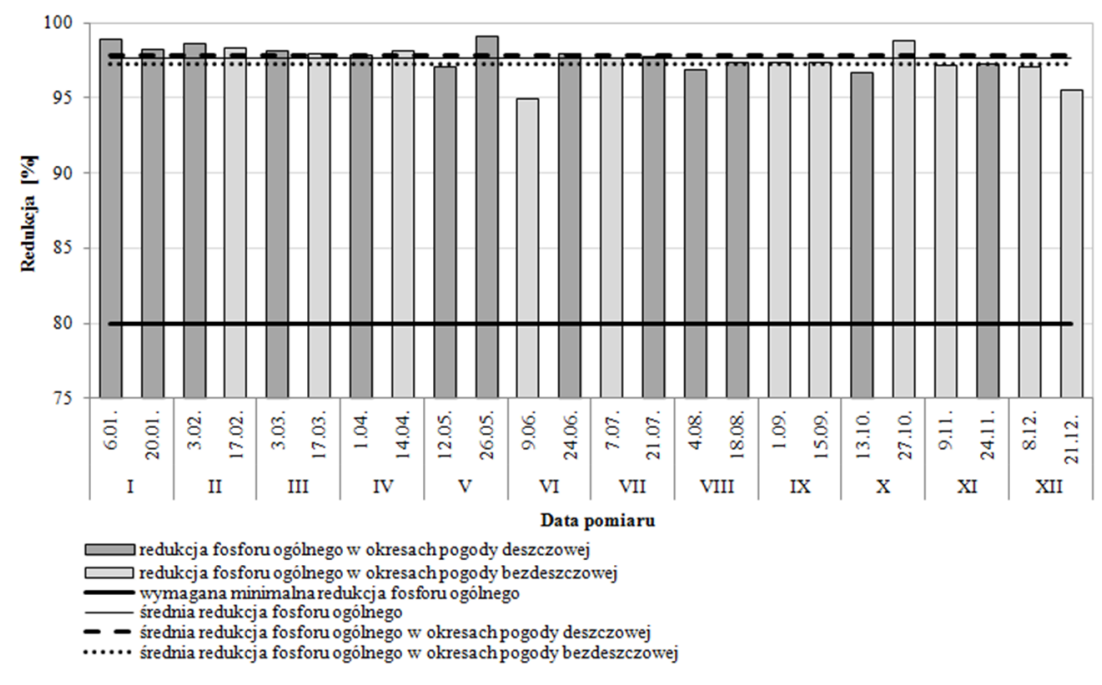

Rys. 2. Redukcja fosforu ogólnego na oczyszczalni ścieków w Trepczy w 2015 roku z uwzględnieniem okresów z pogodą deszczową i bezdeszczową

Fig. 2. Total phosphorus reduction on the Wastewater Treatment Plant in Trepcza in 2015 including rainy and rainless weather periods

Na podstawie zależności (1) określono, że średni udział wód przypadkowych (UWP) w całkowitej ilości ścieków dopływających do oczyszczalni w Trepczy w 2015 roku wyniósł niespełna 5\%. Świadczy to o tym, że na całkowitą ilość ścieków odpływających z terenu sanockiej aglomeracji, wody przypadkowe wpływały w bardzo niewielkim stopniu. Procesy biologicznego oczyszczania ścieków nie były zatem zagrożone skutkami nadmiernego rozcieńczania ścieków surowych niekontrolowanym dopływem wód opadowych, dlatego poziom redukcji związków azotu i fosforu na oczyszczalni w Trepczy, nawet w okresach pogody deszczowej utrzymywał się na tak wysokim poziomie.

\subsection{Redukcja związków biogennych na oczyszczalni ścieków w Przemyślu}

W 2015 roku na oczyszczalni ścieków w Przemyślu azot ogólny redukowany był w większym stopniu niż miało to miejsce na oczyszczalni w Trepczy, także w okresach pogody deszczowej (rys. 5). Średnie stężenie tego wskaźnika w ściekach odprowadzanych do rzeki San było o niespełna $30 \%$ mniejsze od wartości dopuszczalnej $\left(10,0 \mathrm{mg} / \mathrm{dm}^{3}\right)$. Z kolei odnotowana minimalna koncentracja azotu ogólnego w ściekach oczyszczonych $\left(2,9 \mathrm{mg} / \mathrm{dm}^{3}\right)$ była mniejsza od wartości dopuszczalnej o $71,0 \%$, zaś maksymalna koncentracja $\left(9,9 \mathrm{mg} / \mathrm{dm}^{3}\right)$ była niemalże równa wartości granicznej (tabela 1, tabela 3 ). 
Tabela 3. Wartości podstawowych statystyk opisowych dla stężeń azotu ogólnego $\left(\mathrm{N}_{\mathrm{og}}\right)$ i fosforu ogólnego $\left(\mathrm{P}_{\mathrm{og}}\right)$ w ściekach unieszkodliwianych na oczyszczalni w Przemyślu w 2015 roku

Table 3. The values of the basic descriptive statistics for total nitrogen $\left(\mathrm{N}_{\text {tot. }}\right)$ and total phosphorus $\left(\mathrm{P}_{\text {tot. }}\right)$ concentrations in sewage treated on the Wastewater Treatment Plant in Przemyśl in 2015

\begin{tabular}{|c|c|c|c|c|c|}
\hline \multirow{2}{*}{$\begin{array}{c}\text { Nazwa } \\
\text { wskaźnika }\end{array}$} & \multirow{2}{*}{ Jednostka } & \multirow{2}{*}{$\begin{array}{c}\text { Rodzaj } \\
\text { ścieków }\end{array}$} & \multicolumn{3}{|c|}{ Statystyka opisowa } \\
\cline { 3 - 6 } & & Min. & Max. & Srednia \\
\hline \multirow{2}{*}{ azot ogólny $\left(\mathrm{N}_{\mathrm{og}}\right)$} & \multirow{2}{*}{$\mathrm{mg} / \mathrm{dm}^{3}$} & surowe & 39,0 & 216,2 & 85,1 \\
\cline { 3 - 6 } & & oczyszczone & 2,9 & 9,9 & 7,3 \\
\hline \multirow{2}{*}{ fosfor ogólny $\left(\mathrm{P}_{\mathrm{og}}\right)$} & \multirow{2}{*}{$\mathrm{mg} / \mathrm{dm}^{3}$} & surowe & 7,7 & 47,6 & 23,8 \\
\cline { 4 - 6 } & & oczyszczone & 0,13 & 1,20 & 0,64 \\
\hline
\end{tabular}

Wielkości procentowej redukcji związków azotu zmieniały się od odnotowanej dnia 6.07. (dzień bezdeszczowy) wartości 77,0\% do niespełna 97,0\% (22.09. - dzień deszczowy). Zarówno te wartości, jak i wyznaczone średnie wielkości redukcji azotu ogólnego w trakcie trwania pogody deszczowej $\left(\eta_{\text {sr.Nog.deszcz. }}=92,0 \%\right)$ oraz bezdeszczowej $\left(\eta_{\text {śr.Nog.bezd. }}=88,5 \%\right)$, wskazują, że opady atmosferyczne, które wystąpiły w poddanym analizie okresie na obszarze zlewni oczyszczalni w Przemyślu nie wpłynęły na procesy biologicznego usuwania związków azotu (rys. 3).

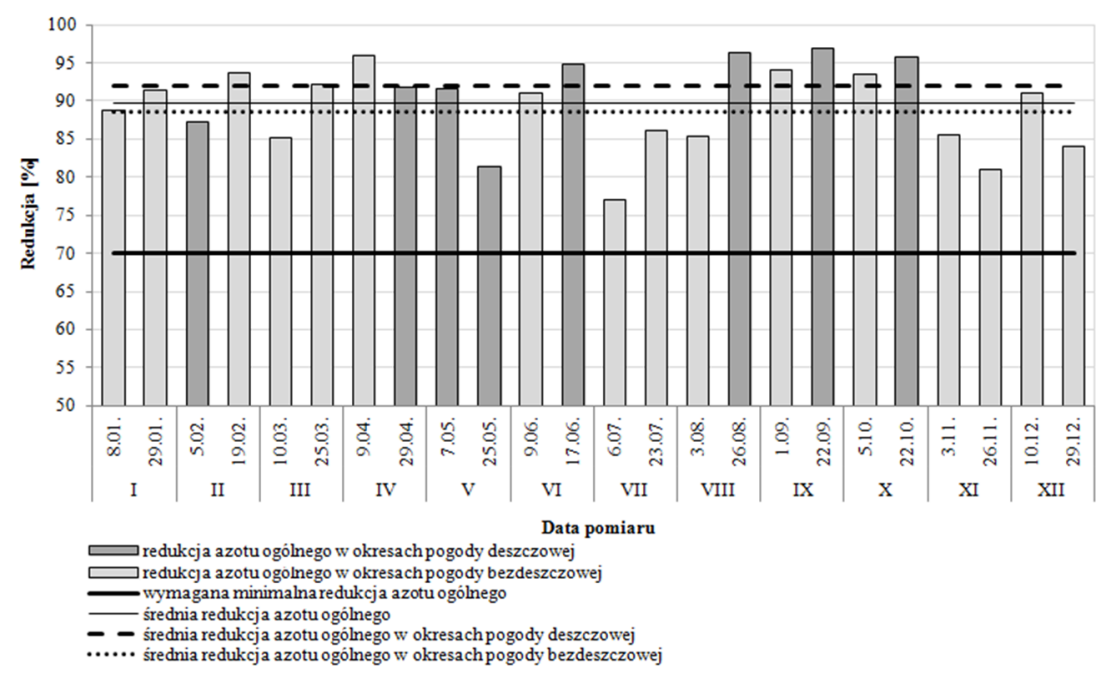

Rys. 3. Redukcja azotu ogólnego na oczyszczalni ścieków w Przemyślu w 2015 roku z uwzględnieniem okresów z pogodą deszczową i bezdeszczową

Fig. 3. Total nitrogen reduction on the Wastewater Treatment Plant in Przemyśl in 2015 including rainy and rainless weather periods

W 2015 roku jakość ścieków odprowadzanych z oczyszczalni w Przemyślu do rzeki San pod kątem stężeń fosforu ogólnego była stosunkowo zróżnicowana, 
ponieważ stężenia te wahały się od $0,13 \mathrm{mg} / \mathrm{dm}^{3}$ do $1,20 \mathrm{mg} / \mathrm{dm}^{3}$, co wskazuje na to, że odnotowywano także wartości przekraczające dopuszczalną koncentrację $\left(1,0 \mathrm{mg} / \mathrm{dm}^{3}\right)$ limitowaną przez obowiązujące Rozporządzenie [19]. Niemniej jednak, wyznaczona średnio-roczna wielkość tego parametru ukształtowała się na poziomie $0,64 \mathrm{mg} / \mathrm{dm}^{3}$, a więc niższym o ponad $35 \%$ od wartości dozwolonej (tabela 1, tabela 3). Podobnie jak w przypadku zmniejszania ilości związków fosforu na sanockiej oczyszczalni, tak i na oczyszczalni w Przemyślu nie zauważa się, aby na zachodzące procesy defosfatacji wpływały warunki pogodowe charakterystyczne dla okresów pogody suchej i mokrej. Potwierdza to wyznaczona wielkość średniej redukcji fosforu ogólnego $\mathrm{w}$ dniach $\mathrm{z}$ opadem $\left(\eta_{\text {sr.Pog.deszcz. }}=97,5 \%\right)$, która była większa od wielkości tego parametru wyznaczonego dla dni bezdeszczowych $\left(\eta_{\text {sr.Pog.bezd. }}=96,4 \%\right)$. Ponadto, zarówno minimalny, jak i maksymalny poziom redukcji fosforu ogólnego przypisuje się pogodzie bezdeszczowej, co dodatkowo potwierdza brak zależności pomiędzy stopniem redukcji zanieczyszczeń, a warunkami pogodowymi związanymi z występowaniem bądź niewystępowaniem opadów atmosferycznych (rys. 4).

Średni udział wód przypadkowych (UWP) w całkowitej ilości ścieków dopływających do oczyszczalni w Przemyślu w 2015 roku był mniejszy niż ten odnotowany w przypadku obiektu w Trepczy, bowiem wyniósł zaledwie 2,7\%. Bardzo niewielka ilość wód przypadkowych, która przedostała się w analizowanym okresie do systemu kanalizacyjnego przemyskiej aglomeracji nie spowodowała rozcieńczenia ścieków surowych poddanych procesom oczyszczania na

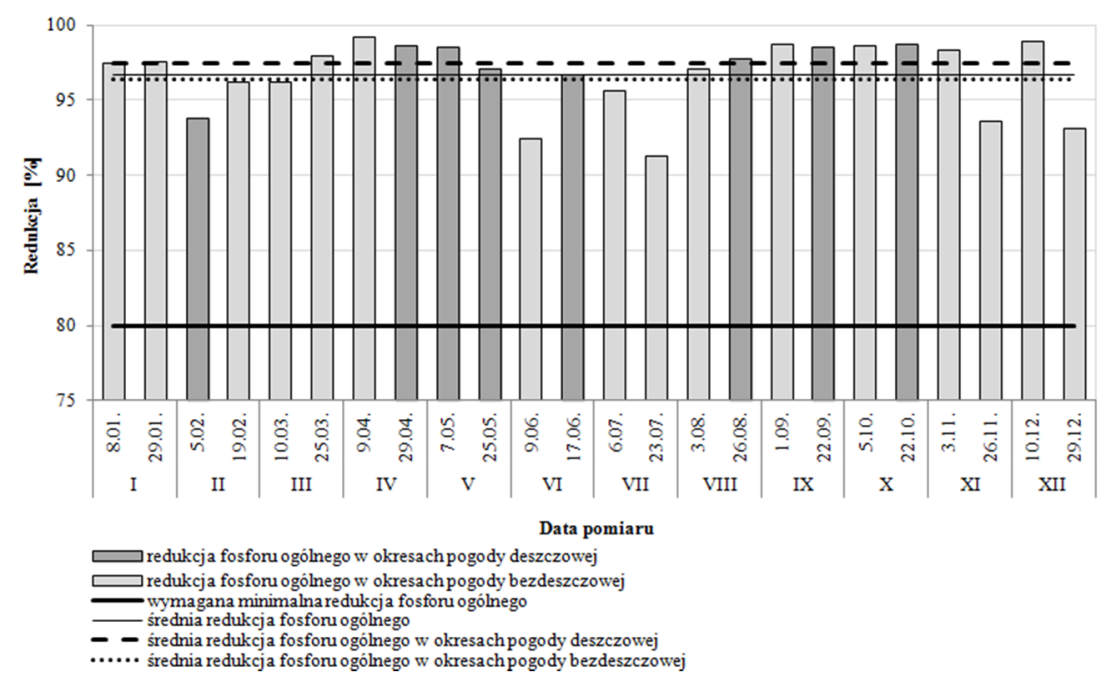

Rys. 4. Redukcja fosforu ogólnego na oczyszczalni ścieków w Przemyślu w 2015 roku z uwzględnieniem okresów z pogodą deszczową i bezdeszczową

Fig. 4. Total phosphorus reduction on the Wastewater Treatment Plant in Przemyśl in 2015 including rainy and rainless weather periods 


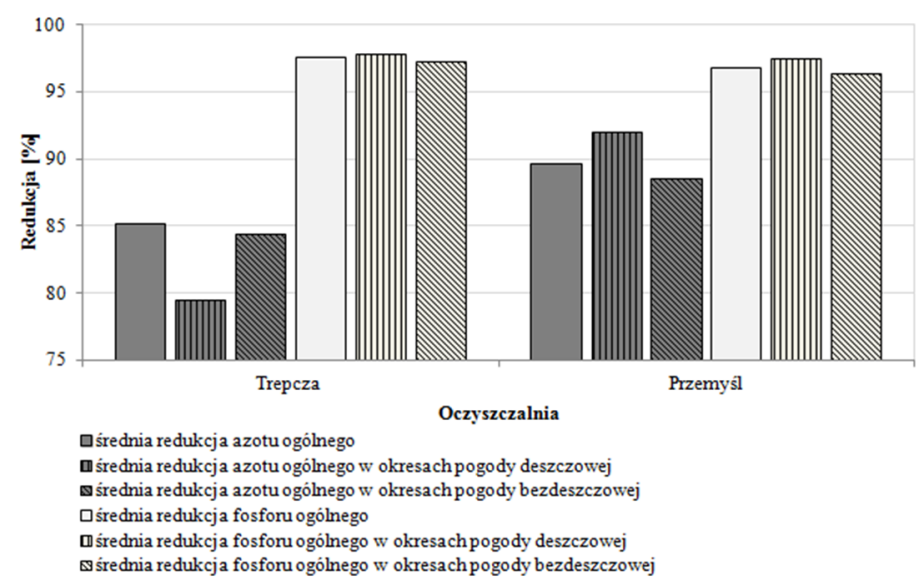

Rys. 5. Redukcja związków biogennych na oczyszczalniach ścieków w Trepczy i w Przemyślu w 2015 roku z uwzględnieniem okresów z pogodą deszczową i bezdeszczową

Fig. 5. Biogenic compounds reduction on the Wastewater Treatment Plants in Trepcza and Przemyśl in 2015 including rainy and rainless weather periods

oczyszczalni w Przemyślu. Dzięki temu, niezależnie od panujących warunków pogodowych, redukcja związków biogennych nie została zaburzona i osiągnęła tak wysoki poziom (rys. 5).

\section{Podsumowanie}

Procesy biologicznego oczyszczania ścieków zachodzące w 2015 roku na oczyszczalniach w Trepczy i w Przemyślu zapewniły wysoki stopień redukcji związków azotu i fosforu do wymaganego poziomu stężeń regulowanego przez obowiązujące prawo, dzięki czemu związki te nie stanowiły zagrożenia dla właściwej jakości wód rzeki San. Pomimo tego, że to drugi z wymienionych obiektów charakteryzował się większą skutecznością w odniesieniu do zmniejszania koncentracji zarówno azotu ogólnego, jak i fosforu ogólnego, to jednak można stwierdzić, że obydwie analizowane oczyszczalnie w właściwy sposób zostały przystosowane do usuwania związków biogennych.

Ponadto w przeprowadzonej analizie wykazano, że na osiągnięty na obydwóch oczyszczalniach ścieków poziom redukcji związków biogennych nie wpłynęły warunki pogodowe związane $\mathrm{z}$ występowaniem bądź niewystępowaniem opadów atmosferycznych. Wyznaczone dla okresów pogody mokrej wielkości średniej redukcji azotu ogólnego i fosforu ogólnego były zbliżone do wartości średniej redukcji wyznaczonej dla pogody suchej. Nie zauważa się zatem związku pomiędzy pojawieniem się opadów atmosferycznych, a zmniejszeniem skuteczności usuwania ze ścieków związków azotu i fosforu, które mogłoby na- 
stąpić np. na skutek nadmiernego rozcieńczania ścieków surowych wodami opadowymi. Określony udział wód przypadkowych oddziałujących w 2015 roku na systemy kanalizacji sanockiej i przemyskiej aglomeracji były na bardzo niskim poziomie, dzięki czemu problem rozcieńczania ścieków, który mógłby zaburzyć prawidłowość przebiegów procesów usuwania związków biogennych nie wystąpił. Dodatkowo można zatem uznać, że stan techniczny infrastruktury kanalizacyjnej funkcjonującej na terenie sanockiej i przemyskiej aglomeracji zapewnia ich właściwą ochronę przed niekontrolowanym dopływem wód przypadkowych.

\section{Literatura}

[1] Sadecka Z.: Podstawy biologicznego oczyszczania ścieków, Wydawnictwo SeidelPrzywecki, Warszawa 2010.

[2] Miksch K., Sikora J.: Biotechnologia ścieków, Wydawnictwo Naukowe PWN, Warszawa 2010.

[3] Królikowska J., Królikowski A., Żaba T.: Kanalizacja: podstawy projektowania, wykonawstwa i eksploatacji, Wydawnictwo PK, Kraków 2015.

[4] Łomotowski J., Szpindor A.: Nowoczesne systemy oczyszczania ścieków, Wydawnictwo Arkady, Warszawa 1999.

[5] Błażejewski R.: Kanalizacja wsi, PZITS, Poznań 2003.

[6] Szpindor A.: Zaopatrzenie w wodę i kanalizacja wsi, Wydawnictwo Arkady, Warszawa 1998.

[7] Kaczor G.: Otwory we włazach studzienek kanalizacyjnych jako jedna z przyczyn przedostawania się wód przypadkowych do sieci rozdzielczej, Infrastruktura i Ekologia Terenów Wiejskich, nr 9, 2009, s. 155-163.

[8] Kaczor G.: Wpływ wiosennych roztopów śniegu na dopływ wód przypadkowych do oczyszczalni ścieków bytowych, Acta Scientiarum Polonorum Formatio Circumiectus, nr 10(2), 2011, s. 27-34.

[9] Zawilski M., Brzezińska A.: Wpływ przeciążenia biologicznej oczyszczalni ścieków w okresach pogody mokrej na jej sprawność, Ochrona Środowiska, nr 2, 2003, s. 37-42.

[10] Zawilski M., Brzezińska A.: Bilans ścieków i ładunków zanieczyszczeń dopływających do oczyszczalni ścieków z uwzględnieniem pogody mokrej, Ochrona Srodowiska, nr 1, 2003, s. 25-30.

[11] Brzezińska A.: Zmiany temperatury ścieków ogólnospławnych na podstawie pomiarów on-line, Inżynieria Ekologiczna, nr 26, 2011, s. 290-302.

[12] Bugajski P., Chmielowski K., Wąsik E.: Wpływ opadów atmosferycznych na temperaturę oraz objętość ścieków w małym systemie kanalizacyjnym, Infrastruktura i Ekologia Terenów Wiejskich, nr 4, 2015, s. 1057-1066.

[13] Bugajski P., Chmielowski K., Kaczor G.: Wpływ wielkości dopływu wód opadowych na skład ścieków surowych w małym systemie kanalizacyjnym, Acta Scientiarum Polonorum Formatio Circumiectus, t. 15, nr 2, 2016, s. 3-11.

[14] Kaczor G.: Oddziaływanie wód przypadkowych na stężenie związków biogennych w ściekach surowych i oczyszczonych podczas pogody mokrej, Infrastruktura i Ekologia Terenów Wiejskich, nr 3, 2012, s. 179-191. 
[15] Raport oddziaływania na środowisko planowanego przedsięwzięcia p.n.: „Przebudowa oczyszczalni ścieków w Trepczy w ramach projektu Poprawa gospodarki wodno-ściekowej w aglomeracji Sanok na działce o nr 566/5 w miejscowości Trepcza”, Sanok, styczeń 2010.

[16] Propozycja planu obszaru aglomeracji Sanok z oczyszczalnią ścieków w Trepczy opracowana w gminie Sanok przy udziale Urzędu Miasta Sanoka, Sanok, wrzesień 2013.

[17] Sprawozdanie z realizacji Krajowego Programu Oczyszczania Ścieków Komunalnych (KPOŚK) za rok 2015.

[18] Winczura M.: Oczyszczalnia ścieków w Przemyślu, Forum Eksploatatora, nr 5(80), 2015, s. 20-23.

[19] Rozporządzenie Ministra Środowiska z dnia 18 listopada 2014 r. w sprawie warunków, jakie należy spełnić przy wprowadzaniu ścieków do wód lub do ziemi, oraz w sprawie substancji szczególnie szkodliwych dla środowiska wodnego [Dz.U. 2014 poz. 1800].

[20] Chmielowski K., Rajchel B., Karnas M.: Analiza skuteczności działania oczyszczalni ścieków „Kujawy”, Czasopismo Inżynierii Lądowej, Środowiska i Architektury - Journal of Civil Engineering, Environment and Architecture. JCEEA, z. 63 (2/I/16), s. 31-42. DOI:10.7862/rb.2016.107.

\title{
REDUCTION OF THE BIOGENIC COMPOUNDS ON SELECTED WASTEWATER TREATMENT PLANTS OF PODKARPACKIE PROVINCE INCLUDING DRY AND WET-WEATHER CONDITIONS
}

\begin{abstract}
S u m m a r y
In the article, the analysis of the reached reduction degree of total nitrogen and total phosphorus in 2015 on the two selected wastewater treatment plants of Podkarpackie Province was performed. As it turns out, the processes of biological sewage treatment on the both research objects provided a high level of biogenic compounds reduction. It was noted that the weather conditions related to the rainy or rainless weather did not affect the effectiveness of nitrogen compounds and phosphorus compounds concentration reduction. There is a risk, that an excessive amounts of rain water in sewage systems can contribute to the reduction of biodegradability organic matter as a consequence of sewage dilution and resulted in reduction sewage treatment effectiveness.
\end{abstract}

Keywords: sewage, wastewater treatment plant, reduction, total nitrogen, total phosphorus, rainless weather, rainy weather

Przestano do redakcji: 4.05.2017 $r$.

Przyjęto do druku: 15.12.2017 r. 